\title{
Faktor Faktor yang Berhubungan dengan Kemandirian Keluarga dalam Perawatan Hipertensi pada Keluarga Binaan Puskesmas Sukaresmi Kabupaten Garut
}

\author{
Udin Rosidin $^{1}$, Theresia Eriyani ${ }^{1}$, Iwan Shalahuddin ${ }^{1}$ \\ ${ }^{1}$ Fakultas Keperawatan Universitas Padjadjaran Kampus Garut, Indonesial \\ e-mail:dinr8629@gmail.com*
}

\begin{abstract}
Cardiovascular disease is now the leading cause of death in the world, including in Indonesia. From the data of Basic Health Research of the Ministry of Health of the Republic of Indonesia, it is known that 31.9\% of deaths in Indonesia are caused by cardiovascular disease. including hypertension by $12.3 \%$, as the second cause of death after stroke. In addition to causing death, hypertension disease is also very high prevalence of $31.7 \%$. The purpose of this study to determine what factors are associated with family independence in implementing hypertension treatment in the assisted family. This research use quantitative approach, with research method is cross sectional. Variables in this research are knowledge, access to health service and behavior of health officer as independent variable and family independence in carrying out hypertension treatment at home is dependent variable. The results showed that the independent variable of knowledge of 50\% respondents good, access to health service 52,6\% far, and behavior of health officer 55,3\% not doing health service standard. While the dependent variable $39.5 \%$ of respondents are at the level of independence I. The conclusion based on the result of statistical test showed that there was a correlation between knowledge with family independence ( $p$ value $=0,042$ ), existence of relation between access to service of debate with family independence level ( $p$ value $=0,044)$ and there is correlation between behavior of health officer to level of independence ( $p$ value $=$ 0,030). Suggestions for Sukaresmi Puskesmas that can be given is to keep doing family coaching, especially on hypertension patient, closer the reach of health service to assisted family and always work together with family in executing family development program
\end{abstract}

Keywords: hypertension, independence, knowledge.

\section{Pendahuluan}

Pembangunan kesehatan adalah bagian dari pembangunan nasional yang bertujuan untuk meningkatkan kesadaran, kemauan dan kemampuan hidup sehat bagi setiap orang agar terwujud derajat kesehatan masyarakat yang setinggi tingginya (Depkes RI, 2004). Untuk menjamin tercapainya tujuan pembangunan kesehatan tersebut sangat ditentukan oleh perkembangan ilmu pengetahuan dan teknologi dibidang kesehatan. Keberhasilan perkembangan ilmu pengetahuan dan teknologi kesehatan tersebut selain berdampak pada hasil pembangunan juga dapat 
meningkatnya produktifitas penduduk, penurunan angka kematian akibat sakit dan meningkatnya usia harapan hidup serta terjadi pergeseran pola penyakit, dari penyakit infeksi dan malnutrisi ke penyakit non infeksi (Sarvasti, 2012).

Pergeseran pola penyakit dari penyakit infeksi dan malnutrisi ke penyakit non infeksi tersebut sangat di tentukan pula oleh perilaku masyarakat yang tidak mendukung hidup sehat. Keadaan ini sesuai dengan konsep transisi epidemiologi yang diperkenalkan oleh Omran (1971) dalam Sarvasti (2012). Konsep transisi epidemiologi tersebut menggambarkan adanya kecenderungan dominasi penyakit degenaritf. Penyakit degeneratif yang merupakan penyebab utama morbiditas dan mortalitas saat ini adalah penyakit kardiovaskuler yaitu jantung koroner, hipertensi dan diabetes melitus (Sarvasti, 2012).

Penyakit kardiovaskuler kini menjadi penyebab utama kematian didunia, termasuk di Indonesia. World Health Organization (WHO) memprediksikan bahwa dimasa yang akan datang $80 \%$ kematian akibat penyakit kardiovaskuler akan terjadi di Negara berkembang (Sarvasti, 2012). Dari data Riset Kesehatan Dasar (Riskesdas) Kementerian Kesehatan tahun 2007 diketahui bahwa 31,9\% kematian di Indonesia disebabkan oleh penyakit kardiovaskuler.
Penyakit kardiovaskuler tersebut diantaranya adalah penyakit hipertensi sebesar $12,3 \%$, sebagai penyebab kematian kedua setelah stroke sebesar $26,9 \%$.

Selain menjadi penyebab kematian, penyakit hipertensi juga prevalensinya sangat tinggi. Sekitar 600 juta penderita hipertensi tersebar dibeberapa negara berkembang. Angka kejadian penyakit hipertensi di Indonesia berkisar $2-18 \%$, yaitu kira kira terdapat 20 juta orang penderita hipertensi (Arza, P. A., \& Yenni, N, 2014)). Indonesia mencapai $31,7 \%$ sedangkan diabetes mellitus $5,7 \%$ dan stroke $0,8 \%$

Dilihat dari jumlah penderita hipertensi yang terjadi di Indonesia, jumlah penderita hipertensi ini tersebar di beberapa provinsi termasuk di Provinsi Jabar. Tingkat prevalensi di Provinsi Jabar mencapai 9,5\% sedangkan rata-rata nasional 7,2 $\%$. Berdasarkan profil kesehatan Kabupaten Garut tahun 2011 pola penyakit rawat inap dan rawat jalan di puskesmas, penyakit hipertensi menduduki urutan ke 6 (4.2\%) setelah influenza $(17,1 \%)$, infeksi saluran nafas akut $(11,2 \%)$, gastroduodenitis tidak spesifik $6,3 \%)$, tukak lambung $(5,6 \%)$, dan gastroenteritis (5,5\%) (Dinas Kesehatan Kab Garut, 2012).

Hipertensi yaitu suatu penyakit dimana tekanan darah berkisar 140/90 $\mathrm{mmHg}$ yang disebabkan oleh faktor-faktor 
pencetus, seperti gaya hidup yang kurang baik seperti merokok, kurangnya olah raga dan pola makan yang tidak sehat. Seperti halnya yang dikatakan oleh Brunner dan Suddart (2000) bahwa Tekanan darah adalah tekanan yang ditimbulkan pada dinding arteri. Tekanan ini sangat dipengaruhi oleh beberapa faktor seperti curah jantung, ketegangan arteri, laju serta kekentalan (viskositas) darah. Tekanan darah biasanya digambarkan sebagai rasio tekanan sistolik terhadapa tekanan diastolik dengan nilai dewasa normalnya berkisar dari 100/60 sampai 140/90.

Melihat karakteristik penyakit tersebut maka penyakit hipertensi perlu ditangani dengan baik. Untuk mencegah hal tersebut perlu ada keterlibatan keluarga sebagai deteksi dini dan pelaksana perawatan hipertensi di rumah. Melihat hal tersebut diperlukan kemandirian keluarga, karena keluarga mempunyai tugas dalam penanganan masalah kesehatan di rumah.

Melihat tugas-tugas keluarga dalam bidang kesehatan sangatlah diperlukan kemandirian keluarga dalam penatalaksanaan penyakit hipertensi di rumah.

Kemandirian keluarga adalah kemampuan dan inisiatif keluarga dalam mengenal dan mengatasi masalah kesehatan secara mandiri. Kemandirian keluarga dalam hal ini adalah perilaku keluarga dalam melaksanakan tindakan keperawatan secara mandiri. Menurut Green yang diambil dari Notoatmodjo (2010) perilaku kesehatan terbentuk dari tiga factor, yaitu 1). Predisposing factors yang terwujud dalam pengetahuan, sikap, kepercayaan, keyakinan dan nilai nilai, 2), Enabling factors yang terwujud dalam lingkungan fisik dan sarana (fasilitas) kesehatan dan 3). Reinforcing factors yang terwujud dalam sikap dan perilaku petugas kesehatan.

$$
\text { Petugas }
$$

kesehatan khususnya tenaga keperawatan di puskesmas mempunya peran yang sangat penting dalam pelaksanaan pembinaan keluarga mandiri. Dalam upaya tersebut, petugas keperawatan sering bekerja sama dengan mahasiswa keperawatan dalam pelaksanaan kegiatan pembinaan keluarga.

$$
\text { Pada tahun } 2013
$$

Puskesmas Sukaresmi Kecamatan

Sukaresmi Kabupaten Garut bekerja sama dengan mahasiswa Akademi Keperawatan Pemerintah Kabupaten Garut melaksanakan kegiatan pembinaan keluarga di tujuh desa wilayah Puskesmas Sukaresmi. Keluarga yang dibina sebanyak 113 keluarga dengan entry point penderita hipertensi sebanyak 38 keluarga $(36,89 \%)$, rheumatoid 26 keluarga $(25,24 \%)$, gastritis 24 keluarga $(23,30 \%)$ dan sisanya 15 keluarga $(14,56 \%)$ adalah penderita TBC, stroke, asma dan diabetes mellitus. Dari 
data tersebut hampir setengahnya keluarga binaan dengan entry point penyakit hipertensi. Pembinaan keluarga dilaksanakan selama lima minggu, dan hasil dari kegiatan tersebut adalah keluarga dengan tingkat kemandirian I sebanyak 47 keluarga (41,59\%), keluarga dengan tingkat kemandirian II ada 42 keluarga $(37,17 \%)$ dan keluarga dengan tingkat kemandirian III sebanyak 24 keluarga $(21,24 \%)$.

Apabila kita lihat data hasil kegiatan pembinaan tersebut, terdapat perbedaan tingkat kemandirian walaupun dibina secara bersamaan. Perbedaan tingkat kemandirian tersebut sangat ditentukan oleh faktor faktor yang mendukung keluarga dalam melaksanakan perawatan di rumah. Dari latar belakang di atas, maka tujuan penelitian ini adalah untuk mengetahui faktor faktor apa saja yang berhubungan dengan kemandirian keluarga dalam melaksanakan perawatan hipertensi pada keluarga binaan Puskesmas Sukaresmi Kabupaten Garut tahun 2014.

\section{Metode Penelitian}

Rancangan penelitian yang akan dilakukan dalam penelitian ini adalah survey analitik dilakukan dengan menggunakan pendekatan kuantitatif, metode penelitiannya adalah cross sectional, karena dalam penelitian ini variabel terikat dan variabel bebas di kumpulkan pada saat bersamaan dan sifatnya sesaat. Ini berarti setiap subyek hanya diobservasisatu kali saja dan pengukuran dilakukan terhadap status karakter atau variabel subyek pada saat pemeriksaan.

$$
\text { Variabel dependen }
$$

penelitian ini adalah kemandirian keluarga dalam melaksanakan perawatan hipertesnsi pada keluarga binaan dan variabel independennya adalah pengetahuan responden, akses ke pelayanan kesehatan dan perilaku petugas kesehatan. Karena variabel tersebut akan rnempengaruhi kepada kemandirian keluarga dalam melaksanakan perawatan hipertensi di rumah.

\section{Hasil dan Pembahasan}

Analisis univariat karakteristik responden dari umur, jenis kelamin, pendidikan dan pekerjaan didapatkan sebagai berikut: rata-rata umur responden adalah 55,24 tahun, umur tertua 73 tahun dan umur termuda 35 tahun. Kurang dari setengahnya responden berada pada kelompok usia 55 - 64 tahun. Sedangkan Jenis kelamin responden lebih dari setengahnya adalah perempuan yaitu sebanyak 55,3\%. Pendidikan responden sebagian besar hanya lulus Sekolah Dasar yaitu berjumlah $86.8 \%$, Sedangkan pekerjaan responden lebih dari setengahnya tidak bekerja yaitu sebesar $72 \%$. 
ISSN : 2354-5852

e-ISSN : 2579-5783

Persepsi responden terhadap jarak rumah ke tempat pelayanan kesehatan lebih dari setengahnya menyatakan rumahnya jauh dari tempat pelayanan kesehatan yaitu $52,6 \%$.

Persepsi responden terhadap perilaku petugas kesehatan, lebih dari setengahnya memiliki persepsi ya melakukan standar pelayanan keperawatan masyarakat, yaitu sebesar 55,3 \%.

Tingkat kemandirian

Keluarga binaan Puskesmas Sukaresmi kurang dari setengahnya berada pada tingkat kemandirian I, yaitu sebanyak $39,5 \%$.

daerah $\begin{gathered}\text { Pengetahuan responden di } \\ \text { binaan Puskesmas }\end{gathered}$
Sukaresmi tentang cara pencegahan dan perawatan hipertensi di rumah setengahnya responden berada pada kelompok yang rnemiliki pengetahuan baik yaitu $50 \%$.

Analisis

biavariat

menggambarkan hubungan antara variabel bebas dengan variabel terikat, Variabel bebas dalam penelitian ini adalah pengetahuan, akses ke pelayanan kesehatan dan perilaku petugas. Sedangkan variabel terikatnya adalah tingkat kemandirian keluarga. Hasil analisis bivariat hubungan pengetahuan dengan kemandirian keluarga disajikan pada tabel 1.

Tabel 1. Analisis Uji Hubungan antara Pengetahuan Responden dengan Kemandirian Keluarga

\begin{tabular}{|c|c|c|c|c|c|c|c|c|}
\hline \multirow{3}{*}{$\begin{array}{l}\text { Penget } \\
\text { ahuan }\end{array}$} & \multicolumn{6}{|c|}{ Kemandirian Keluarga } & \multirow{3}{*}{ Jml } & \multirow{3}{*}{$\mathbf{p}$} \\
\hline & \multicolumn{2}{|c|}{ KM III } & \multicolumn{2}{|c|}{ KM II } & \multicolumn{2}{|c|}{ KM I } & & \\
\hline & f & $\%$ & $\mathbf{f}$ & $\%$ & f & $\%$ & & \\
\hline Baik & 9 & 47,4 & 6 & 31,6 & 4 & 21,1 & 19 & 0,042 \\
\hline Kurang & 3 & 15,8 & 5 & 26,3 & 11 & 57,9 & 19 & \\
\hline Jumlah & 12 & & 11 & & 15 & & 38 & \\
\hline
\end{tabular}

Keterangan: Uji Chi Square

Tabel 1 menunjukkan bahwa ada hubungan pengetahuan dengan kemandirian keluarga dimana $\mathrm{p}=0,042 \quad(\mathrm{p}<0,05)$. Hasil analisis bivariat hubungan akses ke layanan kesehatan dengan kemandirian keluarga disajikan pada tabel 2 . 
ISSN : 2354-5852

e-ISSN : 2579-5783

Tabel 2. Analisis Uji Hubungan Antara Akses ke Yankes dengan Kemandirian Keluarga

\begin{tabular}{|c|c|c|c|c|c|c|c|c|}
\hline \multirow{3}{*}{$\begin{array}{c}\text { Akses } \\
\text { ke } \\
\text { Yank } \\
\text { es }\end{array}$} & \multicolumn{6}{|c|}{ Kemandirian Keluarga } & \multirow{3}{*}{$\begin{array}{c}\text { Jum } \\
\text { lah }\end{array}$} & \multirow{3}{*}{$\begin{array}{c}\mathbf{P} \\
\text { Valu } \\
\mathbf{e}\end{array}$} \\
\hline & \multicolumn{2}{|c|}{ KM III } & \multicolumn{2}{|c|}{ KM II } & \multicolumn{2}{|c|}{ KM I } & & \\
\hline & $\mathbf{f}$ & $\%$ & f & $\%$ & $\mathbf{f}$ & $\%$ & & \\
\hline Dekat & 9 & 50 & 5 & 27,8 & 4 & 22,2 & 18 & 0,044 \\
\hline Jauh & 3 & 15 & 6 & 30 & 11 & 55 & 20 & \\
\hline Jumlah & 12 & & 11 & & 15 & & 38 & \\
\hline
\end{tabular}

Keterangan: Uji Chi Square

Tabel 2 menunjukkan bahwa ada hubungan akses ke pelayanan kesehatan dengan kemandirian keluarga dimana $\mathrm{p}=0,044 \quad(\mathrm{p}<0,05)$. Hasil analisis bivariat hubungan perilaku petugas dengan kemandirian keluarga disajikan pada tabel 3.

Tabel 3. Analisis Uji Hubungan Antara Perilaku Petugas dengan Kemandirian Keluarga

\begin{tabular}{|c|c|c|c|c|c|c|c|c|}
\hline \multirow{3}{*}{$\begin{array}{l}\text { Perilaku } \\
\text { Petugas }\end{array}$} & \multicolumn{6}{|c|}{ Kemandirian Keluarga } & \multirow{3}{*}{$\begin{array}{c}\text { Ju } \\
\text { mla } \\
\mathbf{h}\end{array}$} & \multirow{3}{*}{$\begin{array}{c}\text { P } \\
\text { Valu } \\
\mathbf{e}\end{array}$} \\
\hline & \multicolumn{2}{|c|}{ KM III } & \multicolumn{2}{|c|}{ KM II } & \multicolumn{2}{|c|}{ KM I } & & \\
\hline & f & $\%$ & f & $\%$ & f & $\%$ & & \\
\hline $\begin{array}{l}\text { Melakuk } \\
\text { an }\end{array}$ & 10 & 50 & 5 & 25 & 5 & 25 & 20 & 0,03 \\
\hline Tidak & 2 & 11,1 & 6 & 33,3 & $\begin{array}{l}1 \\
0\end{array}$ & 55,6 & 18 & \\
\hline Jumlah & 12 & & 11 & & $\begin{array}{l}1 \\
5\end{array}$ & & 38 & \\
\hline
\end{tabular}

Keterangan: Uji Chi Square

Hasil analisis bivariat menunjukkan ada hubungan perilaku petugas dengan kemandirian keluarga $(p=0,03)$. Adanya hubungan antara pengetahuan tersebut terhadap tingkat kemandirian keluarga dalam melaksanakan perawatan pada daerah binaan Puskesmas Sukaresmi sesuai dengan pendapat Notoatmodjo (2010) bahwa kemandirian adalah sebuah perilaku yang merupakan respon seseorang terhadap stimulus. Respon tersebut diolah dalam pikiran seseorang berdasarkan pengetahuan yang dimiliknya.

Pendapat lain Lamman (1998) dalam Ardi (2012) menyatakan bahwa kemandirian merupakan suatu kemampuan individu untuk mengatur dirinya sendiri dan tidak tergantung kepada orang lain. Mu'tadin (2002) dalam Ardi (2012) juga menyatakan bahwa kemandirian meliputi perilaku mampu berinisiatif, mampu mengatasi hambatan atau masalah, mempunyai rasa percaya diri dan dapat melakukan sesuatu sendiri 
tanpa bantuan orang lain. Kemampuan-kemampuan tersebut harus didukung oleh pengetahuan yang cukup untuk dapat mandiri dalam mengatasi masalah atau hambatan

Berdasarkan uraian tersebut diatas maka untuk meningkatkan kemandirian keluarga dalam perawatan hipertensi di rumah perlu diberikan pengetahuan secara rutin tentang permasalahan penyakit hipertensi. Dengan pengetahuan yang dimilikinya maka keluarga akan dapat melaksanakan cara pencegahan dan cara perawatan hipertensi. Upaya untuk meningkatkan pengetahuan keluarga tersebut adalah melalui program perawatan kesehatan masyarakat dan secara bertahap melalui kegiatan kunjungan rumah yang dilaksanakan oleh petugas kesehatan. Selain itu dalam pembinaan keluarga untuk dapat meningkatkan kemandirian seseorang dalam melaksanakan perawatan hipertensi di rumah membutuhkan kesempatan, dukungan dan dorongan dari keluarganya, rnaka libatkanlah keluarga dalam setiap pembinaan yang dilaksanakan oleh petugas Puskesmas.

Hubungan Antara Akses ke Yankes dengan Kemandirian Keluarga menunjukkan semakin jauh tempat tinggal responden dengan tempat pe]ayanan kesehatan maka akan semakin rendah tingkat kernandiriannya dan sebaliknya semakin dekat rumah responden dengan tempat pelayanan kesehatan maka akan semakin baik tingkat kemandirian keluarga dalam melaksanakan perawatan hipertensi di rumah. Kesimpulannya adalah pada alpha 5\% ada hubungan yang signifikan antara tingkat kemandirian keluarga dengan persepsi responden tentang akses ke pelayanan kesehatan.

Hasil penelitian tersebut sesuai dengan teori yang dikemukakan oleh L Grenn dalam Notoatmojo (2010), bahwa perilaku seseorang sangat ditentukan oleh sarana yang mendukung terhadap perilaku yang akan dibentuk. Salah satu sarana tersebut adalah keterjangkauan terhadap pelayanan kesehatan. Karena penyakit hipertensi sering terjadi tanpa keluhan maka penyakit hipertensi memerlukan pelayanan rutin dan berkala, baik di sarana pelayanan kesehatan maupun tindakan perawatan di rumah.

Hubungan antara perilaku petugas dengan kemandirian keluarga menunjukan bahwa responden mempunyai persepsi (ya) terhadap petugas kesehatan dalam melaksanakan standar pelayanan kesehatan, responden tersebut cenderung memiliki tingkat kemandirian yang baik dan sebaliknya apabila responden mempunyai persepsi tidak terhadap petugas kesehatan dalam melaksanakan standar pelayanan 
kesehatan, responden tersebut cenderung memiliki tingkat kemandirian yang kurang.

Hasil penelitian sesuai dengan pendapat Sumijatun (2006) Menurut Sumijatun (2006) dalam melaksanakan pembinaan keluarga petugas kesehatan diharuskan mengikuti standart pelayanan kesehatan. Petugas kesehatan yang dimaksud adalah tenaga keperawatan yang mengkoordinir seluruh kegiatan pembinaan keluarga. Standar pelayanan kesehatan yang harus dilaksanakan tersebut yaitu Seluruh pelayanan kesehatan dirumah direncanakan, diorganisir langsung oleh tenaga perawatan professional; Perawat menerapkan konsep teori sebagai dasar pengambilan keputusan; Secara berkelanjutan perawat mengumpulkan data secara menyeluruh, akurat dan sistematis; Perawat menggunakan data pengkajian untuk menentukan diagnosa keperawatan; Perawat mengembangkan rencana, menetapkan tujuan berdasarkan diagnosa keperawatan; Perawat dipandu oleh rencana untuk memberikan kenyamanan, pemulihan, perbaikan dan pendidikan kesehatan; Secara berkelanjutan perawat mengevaluasi respon klien dan keluarga; Perawat bertanggung jawab terhadap kenyamanan klien dan keluarga; Perawat memulai kerjasarna dengan semua pelaksana pelayanan kesehatan;
Perawat menggunakan kode etik dalam melaksanakan perawatan.

Berdasarkan permasalah tersebut diatas peran petugas kesehatan sangatlah penting dalam meningkatkan kemandirian keluarga. Faktor petugas kesehatan sangat penting, petugas kesehatan sebagai pelaksana dalam program perawatan kesehatan masyarakat melalui pembinaan keluarga, memfasilitasi keluarga dalam penggunaan sarana kesehatan, juga petugas kesehatan sebagai pendidik dalam bentuk pemberian penyuluhan kesehatan dan membimbing keluarga dalam melaksanakan tugas keluarga di bidang kesehatan. Sehubungan hal tersebut maka Puskesmas Sukaresmi diharapkan dapat mengembangkan standar pelayanan kesehatan tersebut menjadi standar operasional prosedur yang tetap dan harus dilaksanakan oleh petugas kesehatan setiap akan melaksakan kegiatan

\section{Simpulan}

\subsection{Simpulan}

Simpulan pada penelitian ini adalah: Karakteristik keluarga binaan dengan masalah hipertensi rata-rata umur respond en 55 tahun, Pengetahuan responden tentang cara pencegahan dan perawatan hipertensi pada keluarga binaan setengahnya responden pengetahuan baik. Persepsi responden tentang 


\section{ISSN : 2354-5852 \\ e-ISSN : 2579-5783}

Sarvasti. (2012). Penyakit Jantung

Dan Pembuluh Darah

Penyebab Utama

Kematian Di Dunia. RSU

Husada Utama Surabaya.

Sumijatun dkk. (2006). Konsep

Dasar Keperawatan

Komunitas. Jakarta: EGC .

Suprajitno. (2004). Asuhan

Keperawatan Keluarga.

Jakarta: EGC.
Utarni. (2009). Solusi Sehat Mengatasi Hipertensi. Jakarta: Agromedia Pustaka.

Arza, P. A., \& Yenni, N. (2014). Faktor-Faktor yang Berhubungan dengan Kejadian Hipertensi pada Orang Dewasa di Wilayah Kerja UPTDK Puskesmas Simpang Empat Pasaman Barat Tahun 2012. 'AFIYAH, 1(2). 